REGULAR ARTICLE

\title{
IMPROVING GROWTH AND PRODUCTIVITY OF TOMATO BY SOME BIOSTIMULANTS AND MICRONUTRIENTS WITH OR WITHOUT MULCHING
}

\author{
M. N. HELALY, A. A. ARAFA*, HEBA M. IBRAHIM, K. H. GHONIEM,
}

Department of Agricultural Botany, Faculty of Agriculture, Mansoura University, Egypt

\begin{abstract}
Two field experiments were conducted during 2014 and 2015 growing seasons to assess tomato growth and yield as affected by some biostimulants and micronutrients with or without mulching type. Certain physiological characters were also examined, plant height, the number of branches per plant chlorophyll a, nitrogen \%, red fruit weight and total yield per plant as well as fruit firmness and ascorbic acid concentration in fruit was increased in tomatoes under black plastic mulch compared with bar soil. Application of either biostimulants or micronutrient used to increase all growth and yield characters as well as photosynthetic pigments, ions percentage, and fruit quality. Additive effects were shown under mulching, seaweed extract proved to be the most effective in this respect. It could be recommended that spraying tomato crop at 35 and $50 \mathrm{~d}$ from transplanting with $500 \mathrm{mg} / \mathrm{l}$ seaweed extract under clear or black plastic mulch in order for inducing the highest yield and improve fruit quality.
\end{abstract}

\section{INTRODUCTION}

Tomato (Solanum lycopersicum L., family Solanaceae) is the foremost popular and widely grown vegetable worldwide, for its food and other industrial values [1]. According to FAOSTAT 2015, about 8,533,803 tons of tomato fruits were produced in Egypt. To increase tomato production, several investigations suggested using mulching and/or biostimulants as well as micronutrients [2-4]. Mulch preserves soil moisture, reduces production costs and it is highly effective in controlling weeds, various diseases and pests and reduced soil erosion, leaching of fertilizers [5, 6], and could account for improved yield [7]. Mulch is any material (organic or inorganic) placed on the soil surface to conserve moisture, maintain favorable soil temperatures around plant roots, that results in better plant growth and development [8].

Polyethylene is the foremost used plastic mulching in agriculture as it has numerous qualities when compared to other alternatives [4]. Djigma and Diemkouma [9] proved the benefits of using polyethylene mulch in eggplant and tomato. Organic mulch in specially, straw provide several qulaities like weed control $[4,10]$.

Using biostimulants for promoting plant growth and productivity has recently received increasing attention worldwide [3, 11]. Seaweed extracts (Swe; Ascophyllum nodosum Jol.) as organic biostimulants is fast becoming accepted practice in modern agriculture for sustainable production [12]. Swe contains phytohormones [3], certain micro-and macro-nutrients [14], and secondary metabolites [15]. Swe has been used as a foliar application to accelerate growth, yield, and quality, nutrient uptake, photosynthetic pigments, and resistance to stress factors of many crops [3, 11, 16].

Thiamine (Thi) could be considered as bio-regulators materials that in low concentration exerted a profound impact upon plant growth and development [17]. In this concern Abdel Aziz, Nahed et al. [18] showed an increase in pigments in Thuja orientalis $\mathrm{L}$, plants under Thi treatments. Similarly, Farouk et al., [19] indicate that application of thiamin increased tomato plant growth, photosynthetic pigments, NPK\% and total fruit yield.

Micronutrients have been known to increase the yield and improve the quality of different crops [20, 21, 22]. Using soil organic matter provides most of the micronutrients [23]. Foliar application with differing micronutrients can overcome micronutrient deficiency in the subsoil [20]. Micronutrients play an important role in the physiological processes of many crops. They are required for plant activities like respiration, meristematic development, chlorophyll biosynthesis, photosynthesis, energy system, protein, oil synthesis, phenolic compounds additionally exogenous and applications of micronutrients have been reported in accelerating yield and quality in tomato [24]. Zinc is an important trace element for plants [25], photosynthetic pigment biosynthesis, pollen function and fertilization [26]. Iron and $\mathrm{Zn}$ have many essential roles in plant growth and development [27-29]. The present study aimed to evaluate the impact of two biostimulants (seaweed extract, thiamine) or micronutrients ( $\mathrm{Zn}$ and $\mathrm{Fe}$ ) with or without mulching type on growth, yield and some physiological characters of tomatoes.

\section{Received 20 January 2018; Accepted o2 April 2018}

${ }^{*}$ Corresponding Author

\section{A. A. Arafa}

Department of Agricultural Botany, Faculty of Agriculture, Mansoura University, Egypt

Email: arafa50@mans.edu.eg

( This article is open access and licensed under the terms of the Creative Commons Attribution License (http://creativecommons.org/licenses/by/4.o/) which permits unrestricted, use, distribution and reproduction in any medium, or format for any purpose, even commercially provided the work is properly cited. Attribution - You must give appropriate credit, provide a link to the license, and indicate if changes were made. 


\section{MATERIALS AND METHODS}

Two field experiments were conducted during the two successive early summer seasons of 2014 and 2015 at a private farm $\left(31^{0} 12^{\prime} 30,2 \mathrm{~N} 31^{0} 29 ' 29,4 \mathrm{E}\right)$ in Shirbin, Dakahlia Governorate, Egypt under drip irrigation system with or without mulching types (Bs, Cpm, Bpm, and $\mathrm{Sm}$ ). In addition to distilled water as a control, tow biostimulants denoted (Swe and Thi), as well as ( $\mathrm{Zn}$ and Fe) well evaluated.

\section{Field site}

Before planting, random soil samples of the experimental site were collected (o-30 $\mathrm{cm}$ depth), air dried, grounded, mixed and kept in plastic bags for the analysis. The representative sample was subjected to mechanical and chemical analysis as described by [30]. The soil was loamyclay (25.82 and $25.95 \%$ sand, 32.66 and $32.45 \%$ silt, 41.52 and $41.60 \%$ clay in both experimental season respectively), with normal level of organic matter (1.22 and 1.65\% in both season) The soil $\mathrm{pH}$ (soil paste) was 7.82 and 7.62 and the electrical conductivity (1:5 soil extract) 1.12 and $1.16 \mathrm{ds} \mathrm{m}^{-1}$ in both season respectively.

\section{Experimental design}

A randomized complete block design in a factorial arrangement was adopted with three replications. The experimental unit area was $135 \mathrm{~m}^{2}$ including three ridges, each 30 meters long and $150 \mathrm{~cm}$ apart, and the distance between the hills were $30 \mathrm{~cm}$ apart. The study was performed using determinate fresh market tomato (Solanum lycopersicum L.) cv. Master RS that obtained from Agric. Res. Center (ARC), Ministry of Agric. Egypt.

\section{Planting procedure}

The Tomato seedlings (4-5 mature leaves; $45 \mathrm{~d}$ ) were planted in an open field on $1^{\text {st }}$ March in both seasons, after placing the mulches types by hand. The plowed soil was fertilized with 20 percent of the nitrogen as ammonium nitrate $(33.5 \% \mathrm{~N})$, potassium as potassium sulfate $(48 \%$ $\mathrm{k}_{2} \mathrm{O}$ ) and 50 percent of the phosphorus as calcium superphosphate $\left(\begin{array}{lll}15.5 \% & \mathrm{P}_{2} \mathrm{O}_{5}\end{array}\right)$ from the recommended fertilizer requirements as recommended by ARCE. The remaining amount of nitrogen (urea $46.5 \% \mathrm{~N}$ +ammonium nitrate $33.5 \% \mathrm{~N})$, potassium $\left(48 \% \mathrm{~K}_{2} \mathrm{O}\right)$ and phosphorus as phosphoric acid $\left(85 \% \mathrm{P}_{2} \mathrm{O}_{5}\right)$ were applied through the drip tube throughout growth of plants with other soluble fertilizers such as calcium nitrate $(15.5 \% \mathrm{Ca})$, magnesium sulfate $\left(50 \% \mathrm{Mg}_{2} \mathrm{O}\right)$. Plants were foliar sprayed at early morning with a sprayer (20 1 in volume) to run-off, at 35 and $50 \mathrm{~d}$ from transplanting in each experimental seasons after adding tween 20 as a surfactant. The experiments included the treatments as follows 1-Control (tap water). 2-Seaweed extract (Swe) at $500 \mathrm{mg} / \mathrm{l}$. 3-thiamin (Thi) at $100 \mathrm{mg} / \mathrm{l}$. 4-Zinc chelated (Zn15\% EDTA) at $100 \mathrm{mg} / \mathrm{l} \mathrm{5-}$ Iron chelated (Fe13\% EDTA) at $500 \mathrm{mg} / \mathrm{l}$ under bare soil and or mulching types including clear plastic mulch"50-55 micron; Cpm", black plastic mulch"20-25 micron, Bpm", straw mulch "Sm at 5-7 cm thick".

The crop was irrigated day after day by a trickle irrigation system, consisting of one low-density polyethylene trickle line for each crop row (16 mm diameter) and emitters of 4 Lh-1 separated by $0.30 \mathrm{~m}$. During the growing season, systematic tomato plant protection against fungal diseases was carried out. At 10-day intervals, the following plant protection sprays were applied: Rizolex-T and Ridomil Gold $®$ MZ Pepite 67.8 WG.

\section{Sampling dates and data collection}

At $70 \mathrm{~d}$ from transplanting, a random sample of five plants was taken from each experimental unit to estimate the growth parameters, i.e. (plant height "cm", shoot fresh and dry weights "g"). In addition, like photosynthetic pigment concentration (mg/g FW), as well as ion "N, P and $\mathrm{K}$ " percentage in the shoot were also determined.

At harvesting (110 d from transplanting), the fruits were hand harvested and determined, red fruit weight, colored fruit weight and total yield per plant. A representative sample of 10 healthy fruits from each experimental plot for determination fruit quality, as follows: Total soluble solids (\%); it determined by using Karl Zeiss hand refractometer according to [31]; Fruit firmness $\left(\mathrm{gm} / \mathrm{[0}^{2}{ }^{2}\right)$ were realized by penetrometer Bertuzzi; Ascorbic acid concentration (mg/g FW); it extracted and titrated by 2.6-dichlorophenol indophenol as described by [32].

Photosynthetic pigments (chlorophylls a, b and total carotenoids), were extracted from the blade of the $3^{\text {rd }}$ terminal upper compound leaf on the main stem for $24 \mathrm{~h}$ at laboratory temperature by methanol after adding a trace from sodium carbonate, and determined spectrophotometrically [33]. For ion percentage; ground dried shoot samples were wet digested with $\mathrm{HClO}_{3} / \mathrm{H}_{2} \mathrm{SO}_{4}$, cooled, and brought to the volume of $100 \mathrm{ml}$ using deionized water and kept for ion determinations. Total nitrogen was determined by the microKjeldahl method. Potassium was determined by a flame photometrically [34], and phosphorous using ammonium molybdate and ascorbic acid [35].

\section{Statistical analysis}

Statistical analysis (ANOVA, least significant differences test) was performed at a probability level $\mathrm{P}<0.05$. Percentage data were arcsine transformed before analysis [36].

\section{RESULTS AND DISCUSSION}

\section{Vegetative growth characters}

Data presented in table (1) show that vegetative growth represented as plant height, the number of branches per plant, as well as shoot fresh and dry weights were significantly increased under all mulching type as compared with bare soil in both experimental seasons. The highest values in plant height and branches number per plant in both season, as well as shoot fresh weight in the first season, were obtained due to the application of black plastic mulch (Bpm) as compared with bare soil (Bs). In contrast, the highest shoot dry weight in both seasons and plant fresh weight in the second season were obtained under the application of clear plastic mulch (Cpm) comparing with bare soil.

Regarding the effect of biostimulants or micronutrients on tomato plant growth, the data in the same table assessed that in most cases, all vegetative growth parameters were significantly increased due to the application of either biostimulants or micronutrient. Seaweed extract (Swe) proved to be more effective in this respect.

The interaction results proved that spraying application of biostimulants and micronutrient with mulch types significantly affected all growth and branches characters in the two experimental seasons when compared to control. The highest morphological parameters were recorded in most cases by application of $500 \mathrm{mg} / \mathrm{l}$ Swe under Cpm, meanwhile, the highest branches number per plant were recorded under the treatment of Swe plus Bpm in both seasons respectively. 
Table 1: Vegetative growth characters of tomato plants as affected by biostimulants and micronutrients with or without mulching type at $70 \mathrm{~d}$ from transplanting in both seasons

\begin{tabular}{|c|c|c|c|c|c|c|c|c|c|}
\hline \multirow{2}{*}{\multicolumn{2}{|c|}{$\begin{array}{l}\text { Characters } \\
\text { Treatments }\end{array}$}} & \multicolumn{2}{|c|}{ Plant height(cm) } & \multicolumn{2}{|c|}{$\begin{array}{l}\text { Number of } \\
\text { branches/plant }\end{array}$} & \multicolumn{2}{|c|}{$\begin{array}{l}\text { shoot fresh weight } \\
\text { (g) }\end{array}$} & \multicolumn{2}{|c|}{ shoot dry weight (g) } \\
\hline & & \multirow{2}{*}{$\begin{array}{l}\text { stSeason } \\
56.28\end{array}$} & \multirow{2}{*}{$\begin{array}{l}\text { 2ndSeason }^{\text {nd }} \\
70.68\end{array}$} & \multirow{2}{*}{$\begin{array}{l}\text { stSeason } \\
8.64\end{array}$} & \multirow{2}{*}{$\begin{array}{l}2^{\text {ndSeason }} \\
7.04\end{array}$} & \multirow{2}{*}{$\begin{array}{l}\mathbf{1}^{\text {stSeason }} \\
753.80\end{array}$} & \multirow{2}{*}{$\begin{array}{l}\text { 2ndSeason } \\
671.80\end{array}$} & \multirow{2}{*}{$\begin{array}{l}\text { 1stSeason }^{\text {stSeas }} \\
129.40\end{array}$} & \multirow{2}{*}{$\begin{array}{l}\text { 2 }^{\text {ndSeason }} \\
126.20\end{array}$} \\
\hline « & Bs & & & & & & & & \\
\hline$=$ & $\mathrm{Cpm}$ & 93.24 & 98.50 & 10.16 & 11.32 & 992.00 & 1057.40 & 179.60 & 183.00 \\
\hline$\frac{0}{z}$ & Bpm & 96.60 & 99.72 & 10.48 & 12.12 & 1001.40 & 954.20 & 165.20 & 161.40 \\
\hline$\sum$ & $\mathrm{Sm}$ & 91.44 & 94.44 & 9.88 & 10.34 & 905.80 & 917.80 & 149.40 & 156.40 \\
\hline \multicolumn{2}{|c|}{ LSD at $5 \%$} & 4.41 & 5.13 & 0.92 & 0.77 & 57.70 & 67.85 & 8.46 & 10.28 \\
\hline \multirow{5}{*}{ 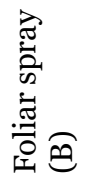 } & $\mathrm{W}$ & $73 \cdot 50$ & 81.32 & 6.75 & 7.97 & 685.00 & 746.00 & 132.75 & $135.5^{0}$ \\
\hline & Swe & 92.30 & 98.40 & 11.25 & 11.87 & 1076.25 & 1065.00 & 171.25 & 180.25 \\
\hline & Thi & 87.45 & 96.90 & 9.90 & 10.92 & 1030.00 & 936.25 & 173.50 & 159.50 \\
\hline & $\mathrm{Zn}$ & 87.75 & 90.12 & 12.10 & 9.95 & 1033.00 & 912.25 & 168.25 & 158.75 \\
\hline & $\mathrm{Fe}$ & 80.95 & 87.42 & 8.95 & 10.30 & 742.00 & 842.00 & 133.75 & 149.75 \\
\hline \multirow[t]{14}{*}{ LSD a } & $5 \%$ & 4.94 & $\mathrm{~ns}$ & 1.02 & 0.86 & $64 \cdot 51$ & $\mathrm{~ns}$ & 9.46 & 11.50 \\
\hline & $\mathrm{Bs}+\mathrm{W}$ & 53.00 & 60.80 & 6.60 & 6.10 & 514.00 & 538.00 & 104.00 & 108.00 \\
\hline & Bs+Swe & 57.40 & $75 \cdot 30$ & 9.00 & 7.20 & 830.00 & 784.00 & 139.00 & 137.00 \\
\hline & Bs+Thi & 56.60 & 83.80 & 9.40 & 8.40 & 910.00 & 625.00 & 149.00 & 124.00 \\
\hline & $\mathrm{Bs}+\mathrm{Zn}$ & 59.00 & 69.20 & 11.60 & 6.30 & 937.00 & 764.00 & 147.00 & 135.00 \\
\hline & $\mathrm{Bs}+\mathrm{Fe}$ & $55 \cdot 40$ & 64.30 & 6.60 & 7.20 & 578.00 & 648.00 & 108.00 & 127.00 \\
\hline & $\mathrm{Cpm}+\mathrm{W}$ & 75.00 & 85.40 & 6.40 & 8.60 & 685.00 & 752.00 & 145.00 & 142.00 \\
\hline & Cpm+Swe & 106.40 & 110.80 & 12.00 & $13 \cdot 30$ & 1315.00 & 1380.00 & 210.00 & 230.00 \\
\hline & Cpm+Thi & 96.60 & 105.30 & 9.40 & 11.70 & 1285.00 & 1160.00 & 222.00 & 190.00 \\
\hline & $\mathrm{Cpm}+\mathrm{Zn}$ & 98.60 & 92.50 & 11.40 & 10.40 & 950.00 & 1050.00 & 174.00 & 187.00 \\
\hline & $\mathrm{Cpm}+\mathrm{Fe}$ & 89.60 & 98.50 & 11.60 & 12.60 & 725.00 & 945.00 & 147.00 & 166.00 \\
\hline & Bpm+W & 83.60 & 92.50 & 7.00 & 9.60 & 887.00 & 930.00 & 153.00 & 158.00 \\
\hline & Bpm+Swe & 107.00 & 105.40 & 13.00 & 14.30 & 1125.00 & 976.00 & 175.00 & 165.00 \\
\hline & Bpm+Thi & 103.60 & 100.060 & 11.00 & 12.20 & 1015.00 & 885.00 & 174.00 & 157.00 \\
\hline \multirow{7}{*}{ 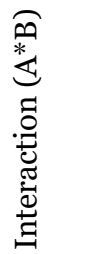 } & $\mathrm{Bpm}+\mathrm{Zn}$ & 96.00 & 102.50 & 12.40 & 12.80 & 1075.00 & 940.00 & 172.00 & 155.00 \\
\hline & $\mathrm{Bpm}+\mathrm{Fe}$ & 92.80 & 97.60 & 9.00 & 11.70 & 905.00 & 1040.00 & 152.00 & 172.00 \\
\hline & $\mathrm{Sm}+\mathrm{W}$ & 82.40 & 86.60 & 7.00 & 7.60 & 654.00 & 764.00 & 129.00 & 134.00 \\
\hline & $\mathrm{Sm}+\mathrm{Swe}$ & 98.40 & 102.10 & 11.00 & 12.70 & 1035.00 & 1120.00 & 161.00 & 189.00 \\
\hline & Sm+Thi & 93.00 & 97.90 & 9.80 & 11.40 & 910.00 & 1075.00 & 149.00 & 167.00 \\
\hline & $\mathrm{Sm}+\mathrm{Zn}$ & 97.40 & 96.30 & 13.00 & 10.30 & 1170.00 & 895.00 & 180.00 & 158.00 \\
\hline & $\mathrm{Sm}+\mathrm{Fe}$ & 86.00 & 89.30 & 8.60 & 9.70 & 760.00 & 735.00 & 128.00 & 134.00 \\
\hline \multicolumn{2}{|c|}{ LSD at 5\% } & 9.88 & 11.47 & 2.05 & 1.73 & 129.02 & 151.73 & 18.93 & 23.00 \\
\hline
\end{tabular}

$\mathrm{Bs}=$ bare soil, $\mathrm{Cpm}=$ clear plastic mulch, Bpm=black plastic mulch, $\mathrm{Sm}=$ straw mulch, $\mathrm{W}=$ water, Swe=seaweed, Thi=thiamine, $\mathrm{Zn}=$ zinc, $\mathrm{Fe}=$ iron

Research over the past few years has demonstrated the stimulating effect of mulch type and shoot growth in different plants [37, 38]. In this concern, Wien [39] found that clear plastic mulch stimulated root extension, increased branching, increased concentration of major nutrients in the shoot. Additionally, Moursy et al. [4] on tomato plants found that, in general, mulches increased plant growth at 90 and $120 \mathrm{~d}$ from transplanting, the most effective in this concern was transparent plastic mulch. Moreover, mulching treatment had the highest stomatal conductance and leaf chlorophyll as well as increased photosynthetic rate that induced plant growth and increased plant fresh and dry weight [4].

The stimulating effect of biostimulants like seaweed extract on plant growth was previously reported $[3,16]$. The promotive effects of biostimulants on plant growth are not yet explained, although there are some theories which probably work together, and can be summarised: 1) Biostimulants like Swe accelerate physiological processes in plants like macro-and micronutrient uptake, cell elongation, enzymatic activity and protein synthesis and finally inducing biomass production [11, 41]. Accordingly, it was found that application of biostimulants increased phosphorous percentage that plays an important role in the biosynthesis and translocation of carbohydrates and stimulation cell division as well as formation of DNA and RNA [24]. 2) Activate root cells and stimulate the biosynthesis of endogenous cytokinins [42]. Cytokinins known to promote cell division, inhibit leaf senescence by blocking the export of photosynthetic to new tissue and stimulating translocation of resources to treated leaves [24], 3) Stimulation the biosynthesis of antioxidants solutes, as in chloroplasts which protect chloroplast and stimulation of chlorophyll biosynthesis [14]. 4) The enriched content of Swe in crude protein and growth promoting hormones, in special, auxin and cytokinins [43]. Proteins are essential for the formation of protoplasm, while growth substances favored rapid cell division and cell multiplication as well as elongation. In addition, Abd El-Aziz Nahed et al., [18] and Farouk [3] found that the application of thiamine and seaweed extract increased significantly vegetative growth represented as plant height, a number of leaves per plant, root length and leaf area, shoot FW and shoot dry weight.

The promotive effect of micronutrient on plant growth was confirmed by Seadh et al., [21] and Farouk et al. [22]. The specific effect of each micronutrient may be summarized 
as a fellow. Foliar spraying with zinc improving the vegetative growth and including the plant capacity for building metabolites. Such response may be due to that zinc is known to play an activator of over 300 enzymes in plants [44] and is directly involved in the biosynthesis of auxin, Indole acetic acid in particular [45] which inducing more dry matter.

Application of $\mathrm{Fe}$ improved plant growth, in special, fresh and dry weight through its role in activating of chlorophyll biosynthesis and photosynthesis [46]. Along with the iron requirement in some heme enzymes and its involvement in the manufacture of the heme group in general, iron has a function in Fe-S proteins, which have a strong involvement with the light-dependent reactions of photosynthesis. As well as being the electron donor for the synthesis of $\mathrm{NADPH}$ in photosystem $\mathrm{I}$, it can reduce nitrate in the reaction catalyzed by nitrite reductase and it is an electron donor for sulfite reductase. All these parameters might have contributed to optimum growth. Apart from this increased concentration of active $\mathrm{Fe}$ in the plants with these treatments enhanced the concentration of nitrogen in the plants. As physiologically active Fe play many roles in the metabolism of nitrogen within the plants by affecting the activities of nitrate reductase, which are directly involved in the assimilation of $\mathrm{N}$ and finally improving plant growth [47].

\section{Photosynthetic pigments}

Table (2) shows that the highest values of total chlorophyll concentrations were obtained under the application of BPM plus water spraying and thiamin in bar soil in the first and second season respectively. Meanwhile, application of $\mathrm{Zn}$ or Fe under CPM gave the highest value of carotenoids in the first and second season respectively.

The present investigation indicated that there was a significant increase in chlorophyll Biostimulants elevated the potassium concentration (table, 3 ), which might have resulted in an increase in chloroplast per cell [24]. The role of Swe in increasing chlorophyll concentration may be due to containing considerable amounts of macro-and micronutrients, amino acids, vitamins and hormonal like activities [13, 48], and/or the high content of betains [49], which possibly increased chlorophyll concentration leading to higher rates of photosynthesis. These results were confirmed in tomato plant [50].

Table 2: Photosynthetic pigment concentration $(\mathrm{mg} / \mathrm{g} \mathrm{FW})$ in the $3^{\text {rd }}$ upper terminal leaflet of tomato plants as affected by biostimulants and micronutrients with or without mulching type at $70 \mathrm{~d}$ from transplanting in both seasons

\begin{tabular}{|c|c|c|c|c|c|c|c|c|c|}
\hline \multirow{2}{*}{\multicolumn{2}{|c|}{ Characters treatments }} & \multicolumn{2}{|c|}{ Chlorophyll A } & \multicolumn{2}{|c|}{ Chlorophyll B } & \multicolumn{2}{|c|}{ Total chlorophyll } & \multicolumn{2}{|c|}{ Total Carotenoids } \\
\hline & & $1^{\text {stSeason }}$ & $2^{\text {ndSeason }}$ & 1 $^{\text {stSeason }}$ & $2^{\text {ndSeason }}$ & $\mathbf{1}^{\text {stSeason }}$ & $2^{\text {ndSeason }}$ & 1 $^{\text {stSeason }}$ & $2^{\text {ndSeason }}$ \\
\hline \multirow{5}{*}{ 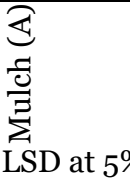 } & Bs & 2.014 & 2.208 & 1.974 & 1.498 & 3.987 & 3.707 & 0.214 & 0.218 \\
\hline & Cpm & 2.082 & 1.851 & 1.755 & 1.271 & 3.838 & 3.121 & 0.242 & 0.160 \\
\hline & $\mathrm{Bpm}$ & 2.347 & 1.888 & 1.606 & 1.297 & 3.860 & 3.186 & 0.166 & 0.102 \\
\hline & $\mathrm{Sm}$ & 1.950 & 2.059 & 1.786 & 1.334 & 3.738 & $3 \cdot 395$ & 0.258 & 0.138 \\
\hline & & 0.157 & 0.125 & 0.128 & ns & 0.240 & 0.074 & 0.008 & 0.005 \\
\hline \multirow{19}{*}{ 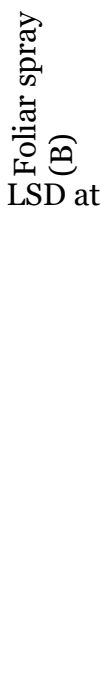 } & W & 2.342 & 1.777 & 1.735 & 1.186 & 4.079 & 2.961 & 0.169 & 0.192 \\
\hline & Swe & 2.077 & 2.035 & 1.878 & 1.400 & 3.954 & 3.435 & 0.231 & 0.066 \\
\hline & Thi & 2.465 & 2.283 & 1.696 & 1.521 & 4.162 & 3.806 & 0.126 & 0.078 \\
\hline & $\mathrm{Zn}$ & 2.050 & 1.937 & 1.874 & 1.224 & 3.808 & 3.163 & 0.216 & 0.260 \\
\hline & $\mathrm{Fe}$ & 1.723 & 1.976 & $1.55^{2}$ & 1.420 & 3.276 & 3.396 & 0.359 & 0.176 \\
\hline & & 0.174 & ns & 0.142 & 0.140 & 0.268 & 0.082 & 0.008 & 0.005 \\
\hline & $\mathrm{Bs}+\mathrm{W}$ & 2.201 & 1.697 & 1.894 & 1.085 & 4.096 & 2.784 & 0.181 & 0.100 \\
\hline & Bs+Swe & 2.020 & 2.372 & 1.819 & 1.631 & 3.832 & 4.003 & 0.184 & 0.044 \\
\hline & Bs+Thi & 2.411 & 2.526 & 1.880 & 1.662 & 4.291 & 4.189 & 0.123 & 0.054 \\
\hline & $\mathrm{Bs}+\mathrm{Zn}$ & 2.227 & 2.361 & 1.721 & 1.574 & 3.949 & 3.935 & 0.406 & 0.750 \\
\hline & $\mathrm{Bs}+\mathrm{Fe}$ & 2.228 & 2.087 & 1.543 & 1.541 & $3 \cdot 771$ & 3.628 & 0.177 & 0.146 \\
\hline & $\mathrm{Cpm}+\mathrm{W}$ & 2.184 & 1.579 & 1.277 & 0.987 & 3.462 & 2.556 & 0.295 & 0.255 \\
\hline & Cpm+Swe & 1.919 & 2.171 & 1.682 & 1.598 & 3.601 & 3.769 & 0.247 & 0.051 \\
\hline & Cpm+Thi & 2.710 & 1.958 & 1.839 & 1.425 & 4.549 & 3.384 & 0.069 & 0.039 \\
\hline & $\mathrm{Cpm}+\mathrm{Zn}$ & 2.368 & 1.905 & 1.851 & 1.080 & 4.220 & 2.986 & 0.062 & 0.093 \\
\hline & $\mathrm{Cpm}+\mathrm{Fe}$ & 1.890 & 1.642 & 1.470 & 1.269 & $3 \cdot 360$ & 2.912 & 0.541 & 0.365 \\
\hline & $\mathrm{Bpm}+\mathrm{W}$ & 1.786 & 2.005 & 1.270 & 1.449 & 3.056 & 3.453 & 0.083 & 0.168 \\
\hline & $\mathrm{Bpm}+\mathrm{Swe}$ & 2.271 & 1.588 & 1.818 & 1.059 & 4.090 & 2.647 & 0.387 & 0.083 \\
\hline & Bpm+Thi & 2.270 & 2.345 & 1.540 & 1.531 & 3.801 & 3.876 & 0.122 & 0.099 \\
\hline \multirow{7}{*}{ 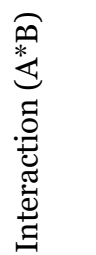 } & $\mathrm{Bpm}+\mathrm{Zn}$ & 2.259 & 1.786 & 1.631 & 1.160 & 3.422 & 2.947 & 0.059 & 0.100 \\
\hline & $\mathrm{Bpm}+\mathrm{Fe}$ & 2.145 & 1.719 & 1.521 & 1.290 & 3.766 & 3.009 & 0.182 & 0.060 \\
\hline & $\mathrm{Sm}+\mathrm{W}$ & 2.086 & 1.829 & 1.876 & 1.223 & 3.965 & 3.054 & 0.118 & 0.247 \\
\hline & Sm+Swe & 2.195 & 2.010 & 1.795 & 1.313 & 3.990 & $3 \cdot 324$ & 0.106 & 0.086 \\
\hline & Sm+Thi & 1.706 & 2.304 & 1.471 & 1.466 & 3.178 & 3.776 & 0.193 & 0.123 \\
\hline & $\mathrm{Sm}+\mathrm{Zn}$ & 1.854 & 1.699 & 1.788 & 1.085 & 3.643 & 2.784 & 0.338 & 0.100 \\
\hline & $\mathrm{Sm}+\mathrm{Fe}$ & 2.280 & 2.457 & 1.328 & 1.580 & 3.609 & 4.083 & 0.536 & 0.134 \\
\hline \multicolumn{2}{|c|}{ LSD at $5 \%$} & 0.348 & 0.285 & 0.288 & 0.282 & 0.540 & 0.165 & 0.020 & 0.014 \\
\hline
\end{tabular}

$\mathrm{Bs}=$ bare soil, $\mathrm{Cpm}=$ clear plastic mulch, Bpm=black plastic mulch, $\mathrm{Sm}=$ straw mulch, $\mathrm{W}=$ water, Swe=seaweed, Thi=thiamine, $\mathrm{Zn}=$ zinc, $\mathrm{Fe}=$ iron 
Fe plays important role in plant growth and development [46] by activating the enzymes aminolevulinic acid synthetase and coproporphyrinogen oxidase or by its role in the conversion of $\mathrm{Mg}$ protoporphyrin to protochlorophyide [51]. Recently, Ozer [4] on tomato confirmed by the present investigation which indicated that all mulch type increased leaf chlorophyll content

\section{Ion content}

Mulching type significantly increased ion percentage in the tomato shoot as compared with bare soil (table 3 ). The highest nitrogen percentage $(0.323$ and $0.331 \%$ in both seasons) was obtained due to Bpm application, meanwhile, the highest percentage of phosphorous (0.298 and $0.307 \%)$ and potassium (1.432 and $1.440 \%)$ was obtained under Cpm comparing with bare soil.

The data also indicated that, using of either biostimulants or micronutrient, in special, seaweed extract without mulching significantly increased ion percentage in the tomato shoot as compared with untreated plants. Spraying Swe treatment proved to be the most effective in this respect. Data also proved that biostimulants application and/or micronutrients with mulch significantly increased ion percentage in the shoot compared with untreated control plants. The highest percentage of this concern was spraying Swe plus Bpm or Cpm in both seasons for $\mathrm{N}$ and either potassium or phosphorous. The promotive effect of biostimulants in ion \% is not fully understood. It may be resulted from improving root system growth, increasing proliferation of root hairs, production of smaller and more ramified lateral roots [52] and to stabilizing membrane permeability, additionally improving nitrogen use efficiency by retarded nitrification processes or inhibited urease activity [53]. Recently, Castaings et al. [54] indicated that application of Swe enhanced nitrogen assimilation. Similarly, Grubinger et al. [55] indicate that clear plastic mulch application increased phosphorous concentration in leaf tissue.

\section{Yield and fruit quality}

Data in table (4) shows that mulching type's significantly increased total yield as well as marketable fruit yield meanwhile decreased un-marketable fruit as compared with bare soil. Foliar application of either biostimulants or micronutrients significantly increased tomato yield compared with untreated control plants. The most effective in this concern was seaweed extract. Moreover, the table proved that application of Swe under Cpm gave the highest tomato yield per plant (4.4 and $4.25 \mathrm{~kg} / \mathrm{plant}$ ).

Table 3: Ion percentage of tomato shoots as affected by biostimulant and micronutrients with or without mulching type at $70 \mathrm{~d}$ from transplanting in both seasons

\begin{tabular}{|c|c|c|c|c|c|c|c|}
\hline \multirow{2}{*}{\multicolumn{2}{|c|}{$\begin{array}{l}\text { Characters } \\
\text { treatments }\end{array}$}} & \multicolumn{2}{|l|}{ Nitrogen } & \multicolumn{2}{|c|}{ Phosphorous } & \multicolumn{2}{|c|}{ Potassium } \\
\hline & & 1 $^{\text {stSeason }}$ & $2^{\text {ndSeason }}$ & $1^{\text {stSeason }}$ & $2^{\text {ndSeason }}$ & 1 $^{\text {stSeason }}$ & $2^{\text {nd }}$ Season \\
\hline \multirow{4}{*}{ 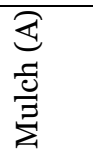 } & Bs & 0.125 & 0.133 & 0.206 & 0.221 & 1.062 & 1.074 \\
\hline & $\mathrm{Cpm}$ & 0.298 & 0.306 & 0.298 & 0.307 & 1.432 & 1.440 \\
\hline & $\mathrm{Bpm}$ & 0.323 & 0.331 & 0.245 & 0.251 & 1.324 & 1.333 \\
\hline & $\mathrm{Sm}$ & 0.723 & 0.281 & 0.256 & 0.261 & 1.297 & 1.303 \\
\hline \multicolumn{2}{|c|}{ LSD at $5 \%$} & 0.125 & 0.125 & 0.017 & 0.017 & 0.097 & 0.097 \\
\hline \multirow{5}{*}{ 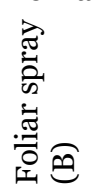 } & $\mathrm{W}$ & 0.076 & 0.083 & 0.175 & 0.184 & 0.912 & 0.920 \\
\hline & Swe & 0.614 & 0.622 & 0.321 & 0.330 & 1.552 & 1.561 \\
\hline & Thi & 0.296 & 0.302 & 0.289 & 0.297 & 1.480 & 1.488 \\
\hline & $\mathrm{Zn}$ & 0.177 & 0.188 & 0.247 & 0.255 & 1.357 & 1.366 \\
\hline & $\mathrm{Fe}$ & 0.110 & 0.118 & 0.226 & 0.234 & 1.092 & 1.101 \\
\hline \multicolumn{2}{|c|}{ LSD at $5 \%$} & 0.120 & 0.120 & 0.020 & 0.020 & $\mathrm{~ns}$ & ns \\
\hline \multirow{20}{*}{ 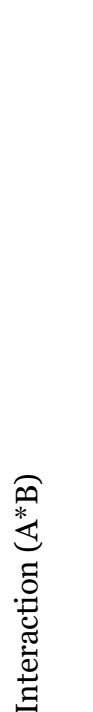 } & $\mathrm{Bs}+\mathrm{W}$ & 0.065 & 0.074 & 0.141 & 0.155 & 0.721 & 0.733 \\
\hline & Bs+Swe & 0.238 & 0.245 & 0.276 & 0.290 & 1.410 & 1.422 \\
\hline & Bs+Thi & 0.162 & 0.168 & 0.234 & 0.250 & 1.310 & 1.322 \\
\hline & $\mathrm{Bs}+\mathrm{Zn}$ & 0.106 & 0.117 & 0.212 & 0.226 & 1.100 & 1.112 \\
\hline & $\mathrm{Bs}+\mathrm{Fe}$ & 0.055 & 0.063 & 0.171 & 0.185 & 0.770 & 0.782 \\
\hline & $\mathrm{Cpm}+\mathrm{W}$ & 0.067 & 0.073 & 0.240 & 0.248 & 1.300 & 1.008 \\
\hline & $\mathrm{Cpm}+$ Swe & 0.719 & 0.726 & 0.397 & 0.407 & 1.770 & 1.778 \\
\hline & $\mathrm{Cpm}+\mathrm{Thi}$ & 0.349 & 0.355 & 0.312 & 0.319 & 1.600 & 1.608 \\
\hline & $\mathrm{Cpm}+\mathrm{Zn}$ & 0.220 & 0.231 & 0.274 & 0.282 & 1.460 & 1.468 \\
\hline & $\mathrm{Cpm}+\mathrm{Fe}$ & 0.139 & 0.147 & 0.271 & 0.279 & 1.330 & 1.338 \\
\hline & $\mathrm{Bpm}+\mathrm{W}$ & 0.095 & 0.098 & 0.161 & 0.167 & 0.951 & 0.960 \\
\hline & Bpm+Swe & 0.916 & 0.925 & 0.276 & 0.282 & 1.540 & 1.549 \\
\hline & Bpm+Thi & 0.334 & 0.340 & 0.309 & 0.315 & 1.540 & 1.549 \\
\hline & $\mathrm{Bpm}+\mathrm{Zn}$ & 0.173 & 0.184 & 0.253 & 0.259 & 1.460 & 1.469 \\
\hline & $\mathrm{Bpm}+\mathrm{Fe}$ & 0.100 & 0.108 & 0.229 & 0.235 & 1.130 & 1.139 \\
\hline & $\mathrm{Sm}+\mathrm{W}$ & 0.080 & 0.088 & 0.161 & 0.166 & 0.976 & 0.982 \\
\hline & $\mathrm{Sm}+$ Swe & 0.586 & 0.593 & 0.336 & 0.341 & 1.490 & 1.496 \\
\hline & Sm+Thi & 0.342 & 0.348 & 0.302 & 0.307 & 1.470 & 1.476 \\
\hline & $\mathrm{Sm}+\mathrm{Zn}$ & 0.212 & 0.223 & 0.250 & 0.255 & 1.410 & 1.416 \\
\hline & $\mathrm{Sm}+\mathrm{Fe}$ & 0.148 & 0.156 & 0.235 & 0.240 & 1.140 & 1.146 \\
\hline \multicolumn{2}{|c|}{ LSD at $5 \%$} & ns & Ns & 0.040 & 0.040 & 0.217 & 0.217 \\
\hline
\end{tabular}

$\mathrm{Bs}=$ bare soil, $\mathrm{Cpm}=$ clear plastic mulch, Bpm=black plastic mulch, $\mathrm{Sm}=$ straw mulch, $\mathrm{W}=$ water, Swe=seaweed, Thi=thiamine, $\mathrm{Zn}=$ zinc, $\mathrm{Fe}=$ iron 
Table 4: Tomato yield as affected by biostimulants and micronutrients with or without mulching type at $110 \mathrm{~d}$ from transplanting in both seasons

\begin{tabular}{|c|c|c|c|c|c|c|c|}
\hline \multirow{2}{*}{$\begin{array}{l}\text { Characters } \\
\text { treatments }\end{array}$} & & \multicolumn{2}{|c|}{ Red fruits weight (gm) } & \multicolumn{2}{|c|}{ Colored fruits weight (gm) } & \multicolumn{2}{|c|}{ Total yield/plant (kg) } \\
\hline & & $1^{\text {st Season }}$ & $2^{\text {ndSeason }}$ & 1 $^{\text {stSeason }}$ & $2^{\text {ndSeason }}$ & 1 $^{\text {st Season }}$ & $2^{\text {ndSeason }}$ \\
\hline \multirow{5}{*}{ 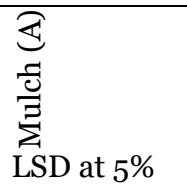 } & Bs & 2205 & 2118 & 580 & 570 & 2.78 & 2.68 \\
\hline & $\mathrm{Cpm}$ & 3013 & 3149 & 470 & 429 & 3.48 & 3.53 \\
\hline & Bpm & 2984 & 2871 & 331 & 344 & $3 \cdot 31$ & 3.21 \\
\hline & $\mathrm{Sm}$ & 2941 & 2720 & 642 & 428 & 3.60 & 3.14 \\
\hline & & 460 & 241 & 90 & 30 & 0.29 & 0.12 \\
\hline \multirow{19}{*}{ 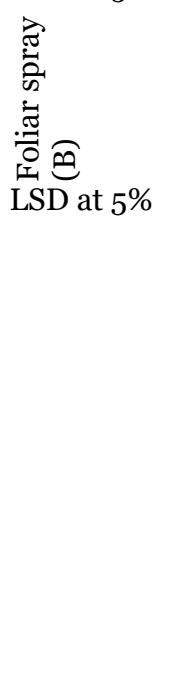 } & $\mathrm{W}$ & 2129 & 2190 & 395 & 335 & 2.52 & 2.52 \\
\hline & Swe & 3405 & 3211 & 666 & 653 & 4.07 & 3.79 \\
\hline & Thi & 3155 & 2977 & 449 & 385 & 3.62 & 3.36 \\
\hline & $\mathrm{Zn}$ & 2770 & 2731 & 582 & 440 & 3.35 & 3.18 \\
\hline & $\mathrm{Fe}$ & 2470 & 2462 & 436 & 400 & 2.90 & 2.86 \\
\hline & & $\mathrm{ns}$ & ns & 101 & 34 & 0.32 & 0.13 \\
\hline & $\mathrm{Bs}+\mathrm{W}$ & 1985 & 1860 & 360 & 340 & 2.34 & 2.20 \\
\hline & Bs+Swe & 2335 & 2150 & 1015 & 970 & 3.35 & 3.12 \\
\hline & Bs+Thi & 2405 & 226 & 545 & 460 & 2.95 & 2.72 \\
\hline & $\mathrm{Bs}+\mathrm{Zn}$ & 2195 & 2340 & 710 & 630 & 2.90 & 2.97 \\
\hline & $\mathrm{Bs}+\mathrm{Fe}$ & 2105 & 1980 & 270 & 450 & 2.37 & 2.43 \\
\hline & $\mathrm{Cpm}+\mathrm{W}$ & 1935 & 2420 & 480 & 370 & 2.41 & 2.79 \\
\hline & $\mathrm{Cpm}+\mathrm{Swe}$ & 3630 & 378 & 825 & 735 & 4.45 & 4.25 \\
\hline & Cpm+Thi & 3470 & 3520 & 318 & 430 & 3.78 & 3.95 \\
\hline & $\mathrm{Cpm}+\mathrm{Zn}$ & 3190 & 2970 & 410 & 350 & 3.60 & 3.38 \\
\hline & $\mathrm{Cpm}+\mathrm{Fe}$ & 2840 & 3050 & 320 & 260 & 3.16 & $3 \cdot 31$ \\
\hline & $\mathrm{Bpm}+\mathrm{W}$ & 2156 & 1950 & 420 & 360 & 2.58 & 2.31 \\
\hline & $\mathrm{Bpm}+$ Swe & 3910 & 3670 & 340 & 640 & 4.25 & 4.31 \\
\hline & Bpm+Thi & 3520 & 3160 & 290 & 160 & 3.81 & 3.32 \\
\hline \multirow{8}{*}{ 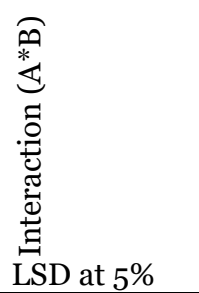 } & $\mathrm{Bpm}+\mathrm{Zn}$ & 2760 & 2945 & 371 & 250 & 3.13 & 3.19 \\
\hline & $\mathrm{Bpm}+\mathrm{Fe}$ & 2565 & 2630 & 235 & 310 & 2.80 & 2.94 \\
\hline & $\mathrm{Sm}+\mathrm{W}$ & 2433 & 2530 & 323 & 270 & 2.75 & 2.80 \\
\hline & $\mathrm{Sm}+$ Swe & 3745 & 3240 & 485 & 270 & 4.23 & 3.51 \\
\hline & $\mathrm{Sm}+\mathrm{Thi}$ & 3225 & 2970 & 645 & 490 & 3.97 & 3.46 \\
\hline & $\mathrm{Sm}+\mathrm{Zn}$ & 2935 & 2670 & 840 & 530 & 3.77 & 3.20 \\
\hline & $\mathrm{Sm}+\mathrm{Fe}$ & 2370 & 2190 & 920 & 580 & 3.29 & 2.77 \\
\hline & & 1028.97 & 540.53 & 203.04 & 68.11 & 0.66 & 0.27 \\
\hline
\end{tabular}

$\mathrm{Bs}=$ bare soil, $\mathrm{Cpm}=$ clear plastic mulch, Bpm=black plastic mulch, $\mathrm{Sm}=$ straw mulch, $\mathrm{W}=$ water, Swe=seaweed, Thi=thiamine, $\mathrm{Zn}=$ zinc, $\mathrm{Fe}=$ iron, concerning fruit quality, table (5) indicates that were detected under Bpm. Also, Cpm gave the high value of T. s. $\mathrm{s}$ in both seasons.

Similar results were reported by erlier works $[4,8,5,6]$. Samaila et al. [57] indicated that soil mulching significantly increased the total yield of tomato fruits compared with bare soil (Bs). Similarly, [58] found that all organic mulches applied in their experiment caused an increase in tomato yield. According to Sinkevičienè et al. [59], yield level of vegetables significantly related to the kind of mulch applied to the soil. The authors added that soil, mulching with grass had the highest yielding effect. This results are in agreement with previous reports [61, 62]. Majkowska-Gadomska et al. [63] and Gajc-Wolska et al. [64] found that sweet pepper fruits cultivated on mulch with straw contained significantly more vitamin C compared to those cultivated on polypropylene fiber mulch.

Micronutrients like Fe or $\mathrm{Zn}$ are important in growth and fruit development [51]. Additionally, $\mathrm{Zn}$ application has a favorable effect on pollen germination, tube elongation and increasing the number of ruptured pollen that results in better fertilization, higher fruit set and final yield [24]. Previous studies support our findings in this study [65-69].

Concerning yield quality, it is well documented from the present study that foliar application of biostimulants accelerated fruit quality. These results were confirmed by $[3,11]$. The favorable influences of biostimulants on the chemical characteristics of tomato fruit may be ascribed to its stimulative effect on photosynthesis process and its concentration of some promoter hormones such as cytokinins which are closely involved in cell division, protein, carbohydrates, and chlorophyll formation [70]. Arafa et al. [71] found that foliar application of seaweed extract has resulted in an increase in potato tuber quality represented as total acidity, total soluble solids and ascorbic acid content. The stimulation effect of biostimulants and micronutrient with or without mulch on tomato yield could be attributed to the presence of plant growth substances, in special, cytokinins in Swe [13], that induced overall plant growth, maintenance of green leaves, and number of branches per plant, increasing photosynthetic pigments as well (table 3), followed by increasing sink capacity fulfilled supply of photoassimilates from green leaves and/or retranslocation of stem reserve [68]. Ozer [4] proved that all mulching type increased tomato yield, fruit firmness and decreased soluble solid content and titratable acidity. 
Table 5: Tomato fruit quality as affected by biostimulants and micronutrients with or without mulching type at $110 \mathrm{~d}$ from transplanting in both seasons

\begin{tabular}{|c|c|c|c|c|c|c|c|}
\hline \multirow{2}{*}{\multicolumn{2}{|c|}{$\begin{array}{l}\text { Characters } \\
\text { treatments }\end{array}$}} & \multicolumn{2}{|c|}{ Fruit firmness $\left(\mathrm{gm} / \mathrm{cm}^{2}\right)$} & \multicolumn{2}{|c|}{ Total soluble solids T. S. S \% } & \multicolumn{2}{|c|}{ Ascorbic acid (mg/g) } \\
\hline & & \multirow{2}{*}{$\begin{array}{l}\mathbf{1}^{\text {st Season }} \\
3.98\end{array}$} & \multirow{2}{*}{$\begin{array}{l}\text { 2 }^{\text {ndSeason }} \\
4.26\end{array}$} & \multirow{2}{*}{$\begin{array}{l}\mathbf{1}^{\text {stSeason }} \\
6.00\end{array}$} & \multirow{2}{*}{$\begin{array}{l}\mathbf{2}^{\text {nd}} \text { Season } \\
6.00\end{array}$} & \multirow{2}{*}{$\begin{array}{l}\mathbf{1}^{\text {st Season }} \\
1.52\end{array}$} & \multirow{2}{*}{$\begin{array}{l}2^{\text {nd Season }} \\
1.40\end{array}$} \\
\hline 2 & Bs & & & & & & \\
\hline 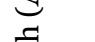 & $\mathrm{Cpm}$ & 4.26 & 4.06 & 6.44 & 6.18 & 1.56 & 1.84 \\
\hline 它 & Bpm & 4.30 & 4.26 & 6.24 & 5.84 & 2.04 & 1.69 \\
\hline$\sum_{i}^{N}$ & $\mathrm{Sm}$ & 4.14 & 4.10 & 6.12 & 5.48 & 1.64 & 1.18 \\
\hline \multicolumn{2}{|c|}{ LSD at $5 \%$} & ns & 0.208 & 0.265 & 0.288 & 0.114 & 0.102 \\
\hline \multirow{6}{*}{ 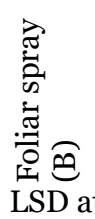 } & $\mathrm{W}$ & $4 \cdot 32$ & $4 \cdot 32$ & $5 \cdot 50$ & $5 \cdot 30$ & 1.92 & 1.58 \\
\hline & Swe & 4.00 & 4.00 & 6.60 & 6.25 & 1.52 & 1.39 \\
\hline & Thi & 4.15 & 4.20 & 6.35 & $5 \cdot 75$ & 1.56 & 1.28 \\
\hline & $\mathrm{Zn}$ & 4.32 & 4.37 & 6.50 & 6.22 & 1.65 & 1.53 \\
\hline & $\mathrm{Fe}$ & 4.05 & 3.95 & 6.05 & 5.85 & 1.80 & 1.89 \\
\hline & $5 \%$ & $\mathrm{Ns}$ & ns & 0.297 & 0.322 & 0.128 & 0.117 \\
\hline \multirow{21}{*}{ 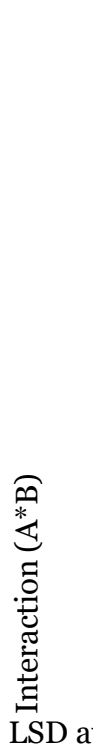 } & $\mathrm{Bs}+\mathrm{W}$ & 3.80 & 4.00 & 5.40 & 5.00 & 1.40 & 1.40 \\
\hline & Bs + Swe & 3.90 & 4.10 & 6.20 & 5.80 & 1.00 & 1.60 \\
\hline & Bs+Thi & 3.40 & 4.80 & 6.40 & 5.40 & 1.20 & 0.96 \\
\hline & $\mathrm{Bs}+\mathrm{Zn}$ & 3.20 & 4.60 & 6.20 & 5.80 & 2.08 & 1.48 \\
\hline & $\mathrm{Bs}+\mathrm{Fe}$ & 3.60 & 3.80 & 5.80 & 5.40 & 1.92 & 1.60 \\
\hline & $\mathrm{Cpm}+\mathrm{W}$ & 4.40 & 4.20 & 5.80 & 5.40 & 1.68 & 2.24 \\
\hline & $\mathrm{Cpm}+$ Swe & 4.40 & 4.20 & 6.80 & 6.40 & 1.80 & 1.20 \\
\hline & $\mathrm{Cpm}+\mathrm{Thi}$ & 4.20 & 4.00 & 6.20 & 5.40 & 1.64 & 1.64 \\
\hline & $\mathrm{Cpm}+\mathrm{Zn}$ & 4.30 & 4.10 & 6.80 & 6.60 & 1.20 & 1.80 \\
\hline & $\mathrm{Cpm}+\mathrm{Fe}$ & 4.00 & 3.80 & 6.60 & 6.20 & 1.48 & 2.36 \\
\hline & $\mathrm{Bpm}+\mathrm{W}$ & 4.50 & 4.70 & 5.60 & 5.80 & 2.36 & 1.36 \\
\hline & $\mathrm{Bpm}+\mathrm{Swe}$ & 4.10 & 3.90 & 6.60 & 6.40 & 2.08 & 1.96 \\
\hline & Bpm+Thi & 4.20 & 4.00 & 6.40 & 6.00 & 1.48 & 1.32 \\
\hline & $\mathrm{Bpm}+\mathrm{Zn}$ & 4.40 & 4.60 & 6.40 & 6.30 & 1.92 & 1.60 \\
\hline & $\mathrm{Bpm}+\mathrm{Fe}$ & 4.30 & 4.10 & 6.20 & 6.40 & 2.36 & 2.24 \\
\hline & $\mathrm{Sm}+\mathrm{W}$ & 4.60 & 4.40 & 5.20 & 5.00 & 2.24 & 1.32 \\
\hline & $\mathrm{Sm}+$ Swe & 3.60 & 3.80 & 6.80 & 6.40 & 1.20 & 0.80 \\
\hline & Sm+Thi & 3.80 & 4.00 & 6.40 & 6.20 & 1.92 & 1.20 \\
\hline & $\mathrm{Sm}+\mathrm{Zn}$ & 4.40 & 4.20 & 6.60 & 6.20 & 1.40 & 1.24 \\
\hline & $\mathrm{Sm}+\mathrm{Fe}$ & 4.30 & 4.10 & 5.60 & 5.40 & 1.44 & 1.36 \\
\hline & $5 \%$ & 0.500 & 0.465 & ns & 0.648 & 0.260 & 0.234 \\
\hline
\end{tabular}

$\mathrm{Bs}=$ bare soil, $\mathrm{Cpm}=$ clear plastic mulch, Bpm=black plastic mulch, $\mathrm{Sm}=$ straw mulch, $\mathrm{W}=$ water, Swe=seaweed, Thi=thiamine, $\mathrm{Zn}=$ zinc, $\mathrm{Fe}=$ iron

\section{CONCLUSION}

From the results it is clear that plastic mulches benefit the growth, and yield of tomato and clear plastic showed superior performance among the plastic mulches and use of Cpm plus spraying tomato plants with $500 \mathrm{mg}$ Swe at $35,50 \mathrm{~d}$ after transplanting give high marketable fruit.

\section{REFERENCES}

1. Wilcox JK, Catignani GL, Lazarus C. Tomatoes and cardiovascular health. Crit. Rev. Food Sci. Nutr., 2003;43, 1-18.

2. Kazemi M. Influence of foliar application of iron, calcium and zinc sulfate on vegetative growth and reproductive characteristics of strawberry cv. 'Pajaro'. Trakia Journal of Sciences, 2014;1, 21-26

3. Farouk S. Improving growth and productivity of potato (Solanum tuberosum L.) by some biostimulants and lithovit with or without boron. Journal of Plant production, Mansoura University 2015;6, 2187-2206.

4. Ozer H. Organic tomato (Solanum lycopersicon L.) production under different mulches in greenhouses. The Journal of Animal and Plant Sciences, 2017;27, 1565-1572.
5. Jordán A, Zavala LM, Gil J. Effects of mulching on soil physical properties and runoffunder semi-arid conditions in Southern Spain. Catena, 2010;81, 77-85.

6. $\mathrm{Mu} \mathrm{L}$, Liang $\mathrm{Y}$, Zhang $\mathrm{C}$, Wangü K, Shi G. Soil respiration of hot pepper (Capsicum annuum L.) under different mulching practices in a greenhouse, including controlling factors in China, Acta Agriculture Scandinavica, Section B-Soil and Plant Science, 2014;37-41

7. Nagalakshmi S, Palanisamy D, Eswaran S, Sreenarayanan VV. Influence of plastic mulching on chili yield and economics. South Indian Hort., 2002;50, 262-265.

8. Abdul-Baki A, Teasdale JR. Sustainable production of fresh-market tomatoes with organic mulches. USDA/ARS Bulletin FB-2279., 1994.

9. Djigma A, Diemkouma D. Plastic mulch in dry tropical zones. Trials on vegetable crops in BurkinaFaso. Plasticulture. 1986;69, 19-24.

10. Kosterna E. The effect of soil mulching with organic mulches, on weed infestation in broccoli and tomatocultivated under polypropylene fiber, and without a cover. J. Plant Prot. Res. 2014;54, 188-198.

11. Calvo P, Nelson L, Kloepper JW. Agricultural uses of plant biostimulants. Plant Soil 2014;383, 3-41. 
12. Stirk WA, Novák O, Strnad M, van Staden J. Cytokinins inmacroalgae. Plant Growth Regul 2003;41, 13-24

13. Kurepin LV, Zaman, M, Pharis, RP. The phytohormonal basis for the plant growth promoting theaction of naturally occurring biostimulators. J Sci Food Agric 2014;94, 1715-1722.

14. Zhang X, Schmidt RE. Hormone-containing products impact on antioxidants status of tall fescue and creeping bent grass subject to drought. Crop science, 2002;40, 1344-1349.

15. MacKinnon SA, Craft CA, Hiltz D, Ugarte R. Improved methods of analysis for betaines in Ascophyllum nodosum and its commercial seaweed extracts. J. Appl. Phycol. 2010;22, 489-494.

16. Arafa AA, Farouk S, Mohamed Hager S. Effect of potassium fertilizers, biostimulants and effective microorganisms of growth, carbohydrates concentration and ion percentage in the shoots of potato plants. J. Plant Production, Mansoura Univ. 2013;4, 15-32.

17. Al-Hakim AMA, Alghalibi A. Thiamin and salicylic acid as biological alternatives for controlling broad bean rot disease. Saudi J. Bio Sci, 2007;14, 201-209.

18. Abdel Aziz Nahed G, Mazher Azza AM, Farahat MM. The response of vegetative growth and chemical constituents of Thuja orientalis L. plant to foliar application of different amino acids at Nubaria. J. American Sci, 2010;6, 295-301.

19. Farouk S, Youssef Safaa A, Ali Abeer A. Exploitation of biostimulants and vitamins as an alternative strategy to control early blight of tomato plants. Asian J Plant Science 2012;11, 36-43.

20. Sienkiewicz-Cholewa U. Effect of foliar and soil application of copper on the level and quality of winter rapeseed yields. J. Elementol., 2008;13, 615-623.

21. Seadh SE, EL-Abady MI, El-Ghamry AM, Farouk S. Influence of micronutrient foliar application and nitrogen fertilization on wheat yield and quality of grain and seed. J. Biological Sciences 2009;9, 851858.

22. Farouk S, Seadh SE, EL-Abady MI, EL-Ghamry AM. Morpho-physiological and anatomical responses of wheat plants to micronutrients and nitrogen fertilization. J. Plant Poduction, Mansoura Univ., 2010;1, 1071-1087.

23. Zhang Y, Stommel JR. Development of SCAR and CAPS markers linked to the Beta gene in tomato. Crop Science 2001;41, 1602-1608

24. Taiz L, Zeiger E. Plant Physiology. 3rd Ed, UK, ISBN: o878938230., 2003.

25. Cakmak I. Enrichment of cereal grains with zinc: Agronomic or genetic biofortification? Plant Soil 2008;302, 1-17.

26. Kaya C, Higgs D. The response of tomato (Lycopersicon esculentum L.) cultivars to foliar application of zinc when grown in sand culture at low zinc. Sci. Hortic., 2002;93, 53-64.

27. Mousavi SR. Zinc in crop production and interaction with phosphorus. Australian Journal of Basic and Applied Sciences. 2011;5, 1503-1509.

28. Chohura P, Kolota E, Komosa A. Effect of fertilization with $\mathrm{Fe}$ chelates on the state of iron nutrition of greenhouse tomato. J. Elementol., 2009;14, 657-664.

29. Davarpanah S, Akbari M, Askari MA, Babalar M, Naddaf ME. Effect of iron foliar application (FeEDDHA) on quantitative and qualitative characteristics of pomegranate CV. "Malas-e-Saveh". World of Sciences Journal, 2013;4, 179-187.

30. Page AI, Miller RH, Keeney TR. Methods of soil analysis part 2. Amer. Soc. Agric. Inc. Madison Wig. 1982

31. AOAC. Official methods of analyses of the association of official analytical chemists, Washington, DC. 1990

32. Sadasivam S, Manickam A. Biochemical methods, Second edition, New age international. India.1996

33. Lichtenthaler HK, Wellbum AR. Determination of total carotenoids and chlorophylls A and B of leaf in Different Solvents. Biol. Soc. Trans., 195;11, 591-592.

34. Kalra YP. Handbook of thereference method for plant analysis. CRC Press, Washington, DC. 1998.

35. Cooper TG. The tools of biochemistry. A WileyInterscience Pub. John Wiley and Sons, New York. 1977.

36. Gomez KA, Gomez AA. Statistical procedures for agricultural research, 2nd, john wileyandsons, New York, NY, 68opp, 1984.

37. Maletta M, Jones HW. Interrelation of root and shoot temperatures on dry matter accumulation and root growth in tomato seedlings. J. Hort. Sci. 1987;624954 .

38. Wien HC, Minotti PL. Increasing yield of tomatoes with plastic mulch and apexremoval. J. Amer. Soc. Hort. Sci. 1988;113, 342-347.

39. Wien HC. Polythene mulch stimulates really root growth and nutrient uptake of transplanted tomatoes. J. Amer. Soc. Hort. Sci., 1993;118, 562-568

40. Moursy SF, Mostafa AF, Solieman YN. Polyethylene and rice straw as soil mulching: reflection of soil mulch type on soil temperature, soil borne diseases, plant growth and yield of tomato. Global Journal of Advance Research, 2015;2, 1497-1519.

41. Rady MM, Mohamed GF. Modulation of salt stress effects on the growth, physio-chemical attributes and yields of Phaseolus vulgaris L. plants by the combined application of salicylic acid and Moringa oleifera leaf extract. Scientia Horticulture; 2015;193, 105-113.

42. Schmidt RE. Biostimulants function in Turf grass nutrition. Oh. D. thesis Emeritus Virginia Tech. USA. 2005.

43. Abdalla Mona M. The potential of Moringa olifera extract as a biostimulant in enhancing the growth, biochemical and hormonal content in rocket (Eroca vesicaria sub sp. Sativa) plants. Afr. J. Crop Sci, 2015;3, 116-122.

44. Fox TT, Guerimot ML. Molecular biology of cation transport in plants. Anmu. Rev. Plant physiol. Plant Mol. Biol., 1998;49, 669-696.

45. Maischner H. Mineral nutrition of higher plants $\left(2^{\text {nd }}\right.$ ed.) p: 355. San Diogo, CA: Academic press, 2002.

46. Rao UK, Reddy KB, Reddy BR. Effect of sulphuric acid on control of lime induced iron chlorosis in groundnut. Indian J. Plant physiology 2001;3, 317319.

47. Hewitt EJ, Notton BA. Structure and properties of higher plant nitrate reductase especially Spinacia oleracea. In: Hewitt E. J., Cutting C. V. (eds). 1980; Nitrogen Assimilation of plants, Academic Press, London, p 227-244.

48. Sridhar S, Rengasamy R. Effect of seaweed liquid fertilizers on the growth, biochemical constituents, and yield of Tagetes erecta, under field trial. Journal of Phytology. 2010;2, 61-68. 
49. Blunden G, Jenkins T, Liu YW. Enhanced leaf chlorophyll levels in plant treated with seaweed extract. J. Appl. Phycol. 1997;8, 535-543.

50. Zodape ST, Abha G, Bhandari SC, Rawat US, Chaudhary DR, Eswaran K, Chikara. Foliar application of seaweed sap as biostimulant for enhancement of yield and quality of tomato (Lycopersicon esculentum Mill.). J. of Scientific and Industrial Research, 2011;70, 215-219.

51. Marschner H. Mineral Nutrition of Higher Plants. 2nd ed. SanDiego: Academic Press, 1995.

52. Canellas LP, Olivares FL, Okorokova-Facanha AL, Facabha AR. Humic acids isolated from earthworm compost enhance root elongation, lateral root emergence, and plasma membrane H-ATPase activity in maize roots. Plant Physiol. 2002;130, 1951-1957.

53. Adani F, Genevi P, Zaccheo P, Zocchi G. The effect of commercial humic acid on tomato plant growth and mineral nutrition. J. Plant Nutr. 1998;21, 561-575.

54. Castaings L, Marchive, C, Meyer C, Krapp A. Nitrogen signalling in Arabidopsis: how to obtain insights into a complex signalling network. J Exp Bot 2011;62, 13911397.

55. Grubinger Hewitt VP, Minotti PL, Wien HC, Turner AD. Tomato response to starter fertilizer, polyethylenemulch,a nd level of soil phosphorus. J. Amer. Soc. Hort. Sci. 1992;118, 212216.

56. Streck NA, Schneider FM, Buriol GA, Heldwein AB. Effect ofpolyethylene mulches on soil temperature and tomato yield in a plastic greenhouse. Scientia Agricola 1995;52, 587-593.

57. Samaila AA, Amans FB, Babaji BA. Yield and fruit quality of tomato (Lycopersicon esculentum Mill) as influenced by mulching, nitrogenand irrigation interval. Intel. Res. J. Agri. Sci. and Soil Sci.,2011;1, 90-95.

58. Saeed and Ahmed. Vegetative growth and yield of tomato as affected by the application of organic mulch and gypsum under saline rhizosphere. Pak. J. Bot. 2009;41, 3093-3105.

59. Sinkevičienè A, JodAuGienè D, PuPAlienè R, urBonienem A. The influence of organic mulches on soil properties and crop yield. Agron. Res. 2009;7, 485-491.

6o. Siborlabane Ch. Effect ofmulching on yield and quality on fresh market tomato. Pages 1-5. In:
Training Report 2000. Training Course in Vegetable Production and Research. ARC-AVRDC. Nakhon Pathom, Thailand.

61. Dzida K, Jarosz Z. Effect of different levels ofnitrogen fertilization and additional foliage feeding on the yield and some elements in leaves and fruits of tomato. Ann. UMCS, Sect. EEE, 2005;XV, 51-58.

62. Najafabadi MMB, Peyvast Gh, Hassanpour AM, Olfati JA, Rabiee M. Mulching effects on the yield and quality of garlic as second crop in rice fields. Int. J. Plant Prod.2012;6, 279-290.

63. Majkowska-Gadomska J, Wierzbicka B, Arcichowska K. Yield and quality of tomato (Lycopersicon esculentum Mill.) fruit harvested from plants grown in mulched soil. Acta Agrobot. 2012;65, 149-156.

64. Gajc-Wolska J, Zielony T, Radzanowska T. Evaluation of yield and fruit quality of new hybridsof sweet pepper (Capsicum annuum L.). Zesz. Nauk. AR we Wrocławiu Rolnictwo 2005;86, 139-147.

65. Crouch IJ, Van Staden J. Evidence for rooting factors in a seaweed concentrate prepared from Ecklonia maxima. J. Plant Physiol., 1991;137, 319-322.

66. Crouch IJ, Smith MT, Van Staden J, Lewis MJ, Hoad GV. Identification of auxins in a commercial seaweed concentrate. J. Plant Physiol., 1992;139, 590-594.

67. Crouch IJ, Beckett RP, Van Staden J. Effect of seaweed concentrate on the growth and mineral nutrition of nutrient stressed lettuce. J. Appl. Phycol., 1990;2, 269-272.

68. Saravanan S, Thamburai, S, Veeraragavatnatnam D, Subbiah A. Effect of seaweed extract and chlormequat on growth and fruit yield of tomato (Lycopersicon esculentum Mill.). Ind J. Agric. Res., 2003;37, 79-87.

69. Kawasaki T. Modern Chromatographic Analysis of Vitamins, 2nd Ed., Vol. 6o, New York, YK: Marcel Dokker, Inc., 1992;pp. 319-354.

70. Featonby-Smith BC, Van Staden J. The effect of seaweed concentrates and fertilizer on growth and the endogenous cytokinins content of Phaseolus vulgaris. South African J. Bot. 1984;3,375-379.

71. Arafa AA, Farouk S, Mohamed Hager S. The response of tuber yield quantity and quality of potato plants and its economic consideration to certain bio regulators, effective microorganisms under potassium fertilization. J. Plant Production, Mansoura University 2012;3, 131-150. 